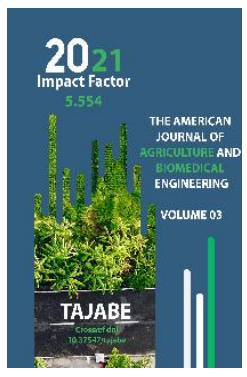

Journal Website: http://theamericanjour nals.com/index.php/taj abe

Copyright: Original content from this work may be used under the terms of the creative commons attributes 4.0 licence.

\section{Importance, Origin And Distribution Of Local Handalak Varieties}

Beknazarov I.O.

PhD Student, Tashkent State Agrarian University, Uzbekistan

Aramov M.X.

Professor, Tashkent State Agrarian University, Termez Branch, Uzbekistan

Loqayev D.B.

Student, Tashkent State Agrarian University, Termez Branch, Uzbekistan

\title{
ABSTRACT
}

Handalak crops have long been widely used in Central Asian folk medicine. In Central Asia, melons have been used to treat tuberculosis, bronchitis, rheumatism, gout, anemia, heart and liver diseases. In malaria, it was considered appropriate to eat soft-melon. Consumption of melons for medicinal purposes is also recommended in modern medicine.

\section{KEYWORDS}

Handalak, varieties, fruits, melon oases, plant gene pool, temperature, seed. sulfur, manganese, zinc, bromine, iron, calcium,

\section{INTRODUCTION}

Uzbek horticulture has a centuries-old history and during this periodHandalakhas been revered as the most valuable, medicinal food loved and consumed by the people. The richness of Handalak is that its composition is rich in nutrients. The Handalaks grown in our country contain $85-92 \%$ water, $8-15 \%$ dry matter, $0.8 \%$ protein, $1.8 \%$ fiber, $6.2 \%$ other carbohydrates, $0.9 \%$ fat, $0.6 \%$ ash, 20 - Contains trace elements such as $30 \mathrm{mg} / \%$ ascorbic acid, 0.03-0.07 mg\% other drugs, phosphorus,

magnesium, potassium, organic and mineral salts, pectin. The fruits of melons are a blessing loved and consumed by many peoples. These fruits are consumed fresh and are considered a raw material for the processing industry. They are a relatively easily digestible, medicinal product and do not lag behind other fruits in terms of taste and nutrition.Handalakis loved and consumed primarily as a thirst-quenching product. 
Therefore, they are widely consumed and used in countries with hot climates. The Institute of Endocrinology of the Ministry of Health of the Republic of Uzbekistan, taking into account the specifics of Central Asia, recommends that a person consume 270 grams of melons, including 150 grams of melons per day.Horticulture is the most important branch of agriculture, which as a science studies the morphology, biology of melon (melon, watermelon and squash) crops and theoretical and practical methods of highyield technology.

Handalak crops are grown in tropical, subtropical and temperate regions of the globe. The countries that grow melons are China, Turkey, India, the United States, Iran, Egypt and Spain. Archaeological excavations have revealed the remains of a melon (7th-8th centuries BC). These crops have long been cultivated in Uzbekistan, as the soil and climatic conditions are favorable for cultivation.

Well-known scientist K.I.Pangalo in his book "Origin and development of melons" writes that the earliest generations of melons were perennials that grow lianas. Currently, there are shrubby and transitional forms of melons. However, most cultivars grow mostly transient.

Handalak (var. Chandalak (Pang.) Greb) - the plant is not large, the stalk is medium length. The fruits are small to medium in size (0.8-3.0 $\mathrm{kg}$ ), round and oblong in shape, often sliced, with yellow or brownish-green bands along the border of the slices. The net is full, covering the surface of the fruit in a mass, partially mesh or without mesh. The skin is thin or medium-thick, soft. The flesh is porous, fibrous, juicy, tender.
The seminal vesicle is not large, but filled with dense seeds. The seeds are large, broadly ovate or oblong-shaped, white, yellowish, yellowish in color. Varieties are mediumyielding. It contains $6.1-8.9$ and $12.0 \%$ of dry matter, $4.0-8.6$ and $10.5 \%$ of sugar. Fruits - low resistance to transport and storage, they are used in local consumption.

Light. Handalak is a light-loving plant of short days. It needs full sunlight and does not like shade. The shortening of the light day to 9-10 hours during the period of germination and the formation of the first true leaf causes the mother flowers to bloom 7-8 days later than the plants grown in full light day.

Heat demand. Handalak is very demanding to heat. The seeds germinate when the soil temperature is $+1313+16^{\circ} \mathrm{C}$. The optimum temperature for the development of Handalak is $+25 \ldots+30^{\circ} \mathrm{C}$. When the temperature drops to a temperature of $+12 \ldots+15^{\circ} \mathrm{C}$, plant growth slows down and the flowers fall off, and at $-1{ }^{\circ} \mathrm{C}$ the plant dies. High temperatures (above $+40^{\circ} \mathrm{C}$ ) adversely affect plant growth.

Melons are xeromorphic, that is, droughtresistant, and have adapted to living in hot, dry and semi-desert climates during the evolutionary development process. This is manifested in the ability of the seed to withstand temperatures up to $+60 \ldots+70^{\circ} \mathrm{C}$ and then germinate in moist soil for 2-3 days. Grasses die when the temperature drops to $0^{\circ}$ C. Self-contained plants are damaged at a temperature of $+3 \ldots+5^{\circ} \mathrm{C}$.

However, like the abundance of moisture during the growth and development of plants, the lack of sufficient temperature prolongs the period from seed germination to flowering of mother flowers. The high demand of the plant for temperature is 
observed during flowering and fruit formation. The optimum temperature during the growth and maturation of fruits is $+30 \ldots+$ $35^{\circ} \mathrm{C}$. High temperatures and humidity during the flowering period have a negative effect on the flowers, causing them to become infertile.

Soil. Handalak is characterized by high adaptability to soil conditions and can be grown in moist meadow soils, gray soils with deep groundwater, as well as in saline soils. However, not all varieties of handalak retain their varietal characteristics in different soils.

Humidity. Despite being relatively resistant to weather and soil drought, handalak is a moisture-loving crop. The different water requirements of the varieties determine the developmental characteristics of the root system. The highest demand for water is observed during the fruiting period. Excess moisture in the soil and air also has a negative effect. High humidity reduces the sugar content of the fruit and allows the development of fungal diseases. Due to the lack of moisture in the soil, the plant makes efficient use of its minimum reserves, which determines the drought tolerance of the variety.

Handalak plant has high drought and heat resistance. Central Asian and Asia Minor subspecies are more heat tolerant than European varieties. Also, summer varieties are generally more heat tolerant than evening varieties.

A characteristic feature of Handalak from other plants is that the mother and father flower buds of this plant are pollinated from the outside for their individuality. This process is mainly carried out by insects, ie bees. Experiments have shown that mechanical, i.e. manual pollination, allows to obtain the desired yield from the trench.

Past crops for Handalak: alfalfa, root crops, onions, cabbage are the best predecessors. The seeds are soaked in a solution of 3-5\% saltmixed and held for 5-7 minutes, then the seeds soaked downremoved, washed in clean water and dried, the rise is raisedthe seeds are discarded. Dried seeds are sown. Fusariosis,copper, zinc and manganese (0.05\% or $0.5 \mathrm{~g} / \mathrm{I})$, iron and barium ( $0.025 \%$ or $2.5 \mathrm{~g} / \mathrm{I}$ ) before sowing handalak seeds to prevent wilting diseasenone of the trace elements should be soaked in the solution.

\section{Central Asian subspecies-Cucumus melo L. ssp. rigidus (Pang.) Phil.}

This subspecies includes varieties that ripen late and ripen during storage. Varieties belonging to different maturing groups are grown in each melon oasis. One of them is;Handalaklar. (var. chandalak. (Pang.) Grebensc.). melons belong to the group of early ripening (growth period 55-70 days), low yield ( 6 to 25 tons per hectare) and unsuitable for long storage.

First of all, it should be noted that the following melon growing oases are allocated in the country: Khorezm, Fergana, Tashkent, Bukhara, Samarkand.

In the field of studying, improving and enriching the local diversity of melons Pangalo K.I., Filov A.I., Goldgauzen M.K., BelKuznetsova V.F., Donskoy P.V., Karimov A.K., Zeman O.G., Dudko P.N., Kulakova M.N., Jiteneva N.E., Kochkarov S.Q., Hakimov A.S., Shchukina A.S., Hakimov R.A. and people's breeders Aligavharov A., Karimshoev U., Tojiev T., Muydinov Sh., and others as 
selection scientists have made a huge contribution.

In Khorezm oasis White-headed, Zamcha, White-suede, Ola-suede, Blue-suede, Blacksuede, Yellow-suede, Red-suede, Turkmen zaami, Bosqovun, Duynak, Local yellow handalak, Handalak Street 14, Tarnek, Urgenji.

In the Fergana oasis, the White Hand, the Yellow Hand, the Black Hand, the Black Hand, the Local Yellow Hand, the Pechak Hand, the Tor Hand, the Big Fruit Hand, the Beshak Hand, the Handalak Street 14, the Chillaki Hand, the Chillaki Melon.

In the Tashkent oasis Ak kallaposh, Gulsar, Zaami, Kokcha, Local yellow handalak, Handalak Kokcha 14.

In the Bukhara oasis Zamcha, Local wolf head, Garmak, Blue head, Samarkand local handalagi, Handalak street 14, Local yellow handalak.

In the Samarkand oasis White-headed, Blueheaded, Zamcha, Zarmiton, Karakash, Karakashka, Holnazar garmak, Large fruit handalak, Samarkand yellow handalak, Local yellow handalak, Handalak Kokcha 14.

In the southern oasisWhite kallaposh, Kok kallaposh, Karakash, Karakashka, Samarkand yellow handalagi, Handalak Kokcha 14, Local yellow handalak varieties are grown.

The plant gene pool of each country is a factor that determines its development, food and economic security. The preservation, reproduction and effective use of the gene pool is the duty of this country to humanity, and no country should be limited to its own gene pool of plants, and scientific research should be conducted to increase the number of species through introduction.

Modern social conditions and the development of agricultural production are influencing the distribution of melon varieties. In the last decade, the number of local varieties grown by amateur melons has decreased, and there is a danger of losing some valuable ancient varieties of folk selection. At the same time, thanks to the efforts of melons, the process of improving existing local varieties through the selection and reproduction of new amazing, promising, sustainable forms and varieties of this crop continues. The germoplasm of local varieties of melons in Central Asia is of great wealth for selection and preservation of the gene pool of melons and is of national importance.

In this regard, scientists of the republic are working to collect existing and endangered local varieties of this crop on expeditions, to preserve them in the collections of scientific institutions, to pass them on to future generations and to study them in detail.

About 40 specimens of handalak varieties are being planted at the Surkhandarya Scientific Experimental Station of the Scientific Research Institute of Vegetables, Melons and Potatoes.

\section{REFERENCES}

1. Azimov B.J., Bo'riev H.Ch., Azimov B.B. Biology of vegetable crops., National Encyclopedia of Uzbekistan. Tashkent, 2001-166 p. 
2. Ostonakulov T.E., Zuev V.I., Qodirkhojaev O.Q. Vegetable growing (Textbook). Tashkent. 2010

3. Zuev V.I., Qodirkhojaev O.Q., Adilov M.M., Akromov U.I. Vegetable and horticulture (Practical training), 2009

4. Qodirhojaev.O., Muhamedov M.M. Technology of growing vegetable crops (m. Text). Tashkent - 2000

5. Abdullaev A.Q., Arginboev H.A., Abdullaev H.U. Agrometeorology. Recommended as a textbook by the Scientific and Methodological Council of the National University of Uzbekistan named after Mirzo Ulugbek. Tashkent2006. 